\title{
Reviewing, as an Extraordinary Mean of Appeal
}

\section{Lirime Çukaj (Papa)}

Prof. As. Dr. at University of Tirana, Faculty of Law, Lecture at the Criminal Law Department

Msc. Denisa Laçi

\section{Abstract}

One of the fundamental rights that a subject in criminal proceedings owns, is the right to appellate a court decision, which besides the usual means of appeal in Albanian system of justice, are guaranteed also by extraordinary means of appeal as it's reviewing a decision despites any deadline of appeal. The review is the means of appeal, which aims to strike court decisions, which have become final, with positive expectations in each case, to improve the status of the offender. In the constitutional of Albania of 1998 this institute, was not regulated explicitly, but there was foreseen as part of jurisdiction of the High Court, where clearly was put that the high court had preliminary and reviewing jurisdiction. In the framework of the Justice Reforming in 2016, the HC Was stripped of its reviewing jurisdiction. The competence to reexamine a final court decision was given to the first instance court, which can judge in these cases any type of decision that fulfils the criteria to be reviewed, despite the fact if this decision has been taken by an Appeal Court or the High Court. Undertaking legal changes in constitute and Code of Criminal Procedure for this institute came as response/regarding to the legal vacuum found in Albanian system of justice as well as the contractual practice with the ECHR, established by the Albanian court. The Albanian system did not have the effective means to guarantee the right to a fair legal process, the implementation of which has been ascertained by the ECHR in some of the decisions given against Albania as (Xheraj vs Albania; Lika vs Albania etc.). Because of that, in the $\mathrm{CPC}$, become larger the number of cases, when the reexamining of this type of court decision could be done. The purpose of this article is to present in a comparative form the institute of reviewing court decisions; it aims to prescribe how this mean of appeal was and how it is now after the reform, to continue further with the findings of problems that have arisen from the practice of implementing this means of appeal from its latest changes. Justice reform is still in its infancy and therefore the practice of elaborating this tool has been insufficient.

Keywords: Constitution, Review, final decision, high Court, ECHR, judgment in absentia, regular legal process.

\section{Introduction}

The right to appeal is one of the means that subjects have in any kind of process to guarantee the respect of their rights. An appeal is precisely the legal mean that ensures the individual's access to justice, and to the courts. This legal remedy has found legal regulation starting from international acts, constitution to by laws that operate within a country. The means of appeal, 
legal systems have classified into two categories, ordinary means of appeal (appeal and recourse) and extraordinary means of appeal (Review and Restoration of the Right to Appeal in time). For the purpose of study in this article, we are presenting the characteristics that the review has, as an extraordinary mean of appeal.

Importance that characterized this mean, is that through it, a decision, which has become final and is already being executed or the execution, may have ended can be challenged. Emphasizing that this is not a rule, but it is an exception to the rule, only to protect the function of administering justice by the state authority and at the same time to protect the interests and rights of the parties in the judicial process. The Constitution ensures in Article 43 the right to appeal, where although it does not explicitly cite the review of the appeal, in the spirit of the law it is implied. Article 141 provided for the review jurisdiction of the High Court, implying that the court competent to adjudicate the review was the High Court. The latter, being a court of law, after undertaking the reform the lawmaker properly limited HC review jurisdiction by passing the review of the revision request to the court of first instance, which then forwards it to the competent court depending on the decision contested.

The review institute underwent significant changes both in terms of expanding the cases when it can be applied and changes related to the procedure for its implementation. These changes implemented by law no. 37/2017, came in response to findings from court practice over the years, or recommendations left by the ECHR, regarding Albania. Within this institute, this paper aims to analyse in a comparative aspect how it was and how this mean of appeal is actually. Additionally a great focus of our study is highlighting problems raised through courts practice and measures taken to sole these. In the situation where the implementation of the reform is still in the first steps of implementation, the analysis of this means of appeal is of particular importance for the doctrine of law.

\section{Methodology}

Analytical Methods - analysing the provisions of procedures, highlighting the innovations and shortcomings of this mean of appeal.

Comparative methodology - We have made a comparison of the provisions how this institution was and how it is now after the Justice Reform undertaken in 2017.In this way we can understand which the problems of this institution were and how well these problems the Justice reform addressed. On the other hand, from combination of these two searching methods, we can conclude weather they may have problems that may need solutions even after the legal changes, which we will recommend at the end of the article.

\section{Review Characteristics}

Review is an extraordinary and exceptional mean of appeal against a final criminal court decision, which cannot be challenged through ordinary means of appeal (appeal and recourse). In these circumstances, when the ordinary means of appeal have been exhausted, the decision is final and the case is considered closed based on the principle of res judicata. ${ }^{1}$ The Constitution in here provisions foreseen the right of subjects to appeal ${ }^{2}$, where despite the fact that the review is not explicitly cited, it is implied by interpreting in relation to other

\footnotetext{
${ }^{1}$ See section 2 Final decision, meaning and cases

2 Constitute of Republic of Albania, amended 2016 Article 43 "Everyone has the right to appeal a judicial decision to a higher court, except when the Constitution provides otherwise."
} 
constitutional provisions. Article 34 of the Constitution of the Republic of Albania provides that: "No one may be sentenced more than once for the same criminal offense or be tried again, except for cases when the re-adjudication of the case is ordered by a higher court, in the manner specified by law"

In this article, are foreseen three of the most important principles of criminal procedure are foreseen: i) the principle of non-trial twice for the same criminal offense (ne bis in idem) ii) the principle of legal certainty (res judicata) and iii) the possibility of re-opening of the criminal case as an opportunity to deviate from the principle of legal certainty. With regard to the third principle, the possibility of reopening the criminal case determines that revision is allowed when conditions according to the legal provisions are filled. Such a sanction is foreseen also in protocol no. 7 of the European Convention on Human Rights ${ }^{1}$. Deviation from the principle of legal certainty through revision aims to correct a judicial error in the administration of justice. In relation to this issue, the ECHR has stated in several cases that Court considers that the requirements of legal certainty are not absolute. "Departures from that principle are justified only when made necessary by circumstances of a substantial and compelling character". ${ }^{2}$

Referring to article 449 of CPC, before changes happen, we could see two kind of application of revision i. extra ordinem pro reo and ii. Contra reum. In the first case, the pro reo review based on in the request of the convicted with purpose of bringing about a re-evaluation of the truth, with aim to challenge a sentencing decision and the possibility that re-opening of trial potentially brings the possibility of acquittal. Substantially the review must consist in the principle that justice must break the procedural framework of the final judgment closure.

In the second, contra reum revision asked by prosecutor, the subject is objection of a wrong innocence decision given by the court. The purpose was to punish those who commit a crime and due to judicial system mistakes, remain unpunished, which came against the principle of administering justice. The provision we can see came in contradiction with the principle reformation in peius, because it aggravates the position of the convicted. In the other hand, this provision has been limited by putting the deadline of 5 years in way to present a request for revision of acquittal by the prosecutor.

Through law, No.35/2017 the code changed relating to this provision. From now one the acquittal decision cannot be subject of revision procedure, giving in this way prevalence to reformation in peius principle. ${ }^{3}$ As prescribed after the changes implemented following the revision would be applied only in one way, in favour of the convicted that means would be only extra ordinem pro reo. As sanctioned in this article, legitimate persons to ask for revision are the convicted, the familiars when the latter is dead and the prosecutor.

\footnotetext{
1 Protocol no. 7 of the European Convention on Human Rights Article 4, Right not to be tried or punished twice "1. No one shall be liable to be tried or punished again in criminal proceedings under the jurisdiction of the same State for an offence for which he has already been finally acquitted or convicted in accordance with the law and penal procedure of that State. 2. The provisions of the preceding paragraph shall not prevent the reopening of the case in accordance with the law and penal procedure of the State concerned, if there is evidence of new or newly discovered facts, or if there has been a fundamental defect in the previous proceedings, which could affect the outcome of the case." 2 Ryabykh vs Rusia nr.52854/99, fq.52, ECHR 2003-IX). Bratyakin vs Rusia nr.53203/99, fq.63-68, 15 December 2005,

${ }^{3}$ CPC, amended article 449/2The revision of the final judgment of acquittal or conviction is not allowed when it aims at aggravating the position of the convicted person
} 
The reasons, for which a review of a final decision may be requested, are in function of the ratio, which is to put an end to consequences of an unfair decision that is final. The request for consideration should be based on legal reason on which reviewing of decision arises, necessarily accompanied by the supporting documents, which support the claim. With law $35 / 2017$, these legal reasons underwent an extension as a need of practice over the years. ${ }^{1}$

Finally, the extraordinary character of this institution noted by the fact that its presentation is not limited with deadlines, except the three cases that justice reform on CPC, which will be addressed in the following of this paper.

\section{Final decision, meaning and cases.}

Albanian practice has presented a confusion regarding interpretation of what final decision means. What raised for discussion and as a need to unify the case law at High Court (HC)) was that in theoretical terms terminology "enforceable decision", "final decision" and "res judicata" are expressions of the same legal notion, or these are different concepts from each other?

In unifying its practice, $\mathrm{HC}$ made an extended interpretation of these three concepts ${ }^{2}$.

We must first understand that the final decision in terms of application of review institute refers to decision that has taken form of res judicata. In order to face such a form, decision must meet one of following two conditions:

Usual means of appeal have been exhausted, such as appeal and recourse to High Court, which means that parties have exhausted all three stages of the trial, or

$\mathrm{He}$ /she has overpassed deadlines for appealing, as provided by law for opposing a court decision.

In both of above cases, we can say that we are in front of the final decisions that have taken the form of res judicata, and therefore can be subject to review when the legal conditions foreseen for revision in $\mathrm{CPC}$, are met.

On the other hand, we have final decisions that do not constitute res judicata, here we refer to cases of decisions that are enforceable but do not constitute a judgment because they are subject to trial by highest judicial instances. Here we can mention, for example, the decisions of Court of Appeals, which are enforceable because recourse to High Court does not automatically suspend execution of decision, but does not constitute a judgment. In this case, the principle is that any final decision is always enforceable, but not the other way around, as not every enforceable decision is a res judicata.

As we have stated above, we can say that object of the review includes decisions of three courts with the only condition that this decision have taken the form of what is known as res judicata.

If we look at international doctrine according to the definition contained in the explanatory report of the European Convention on the International Validity of Criminal Judgments, a decision is final "if, according to the traditional expression, it has acquired the force of res judicata. This is the case when it is irrevocable, that is to say, when no further ordinary

\footnotetext{
1 See section 3. "Revision cases"

2http://www.gjykataelarte.gov.al/web/Vendime_Unifikuese_39_1.php Decision no. 3 date 03.11.2014.
} 
remedies are available or when the parties have exhausted such remedies or have permitted the time limit to expire without availing themselves of them

A case may, however, be reopened in accordance with the law of the State concerned if there is evidence of new or newly discovered facts, or if it appears that there has been a fundamental defect in the proceedings, which could affect the outcome of the case either in favour of the person or to his detriment 1 .

According to this definition, principle of not aggravating position of defendant/reformation in peius, does not apply that means that a decision even though it will aggravate the status of the convicted, may be revised, which is not applicable according to our legal system after the latest changes. Despite that, we shall mention that some legal systems have implemented such a way of application of this institute. ${ }^{2}$ Regarding to that, ECHR in here practice has given her opinion in cases such as Brumarescu vs Rumania. According to the Rumanian system, it foreseen that the General Prosecutor, for any type of reason could asked in HC, for a re-opening of judicial proceedings, which were res judicata. ECHR in the decision explained that this was a violation of principle for legal certainty ${ }^{3}$.

This unifying practice has also been a good impetus for Albanian justice system that at time of undertaking justice reform has explicitly cited cases of a final decision 4 .

An important issue related with co-defendants in a trial that needs a special attention is, what happens to the defendant, in cases where some of them can appeal and some cannot. Does one's appeal have an effect on the others? Referring to legal provision implemented with undertaking of reform, we find that the decision becomes final for defendant who does not represent an appeal, with passing of deadline for appeal, if prosecutor, despite the appeal that

\footnotetext{
1Explanatory Report to the Protocol No. 7 " To the Convention for the Protection of Human Rights and Fundamental Freedoms" Strasbourg, 22.XI.1984, article 3 ph. 22 p. 6 referring to Commentary on Article 1. a: Explanatory report of the European Convention on the international Validity of Criminal Judgments, publication of the Council of Europe, 1970, p. 22.

2 Ruse System, sanctions what is known as the "Supervisory Review", according to which the prosecutor in any case for any reason, although this may aggravate the position of the convict may request the reopening of the process for decisions that have taken the form of res judicata. DirectorateGeneral for Human Rights Council of Europe F-67075, Strasbourg Cedex "The right to a fair trial", p. 65 ${ }^{3}$ https://hudoc.echr.coe.int/eng\#\{\%22itemid\%22:[\%22001-58337\%22]\} pg.61. "The right to a fair hearing before a tribunal as guaranteed by Article $6 \S 1$ of the Convention must be interpreted in the light of the Preamble to the Convention, which declares, among other things, the rule of law to be part of the common heritage of the Contracting States. One of the fundamental aspects of the rule of law is the principle of legal certainty, which requires, inter alia, that where the courts have finally determined an issue, their ruling should not be called into question."

${ }^{4}$ Criminal Procedure Code, article 462/3 " The following are final decisions: a) the first instance court decision when it is not appealed by the parties within the legal time limit, when it is non-appealable or when the appeal is not admitted for the reasons provided for in article 420 of this Code. In cases with co-defendants, the decision shall become final for the defendant who has not filed an appeal, notwithstanding the appeal of other co-defendants, if the prosecutor has not filed an appeal. When the prosecutor has not filed an appeal and the case is examined on the basis of the appeal of other codefendants, the decision shall become final for the defendant who has not filed an appeal in a trial with co-defendants, notwithstanding the appeal filed with by the other co-defendants; b) the decision of the appeal court, when it finally settles the case, pursuant to letters "a", "b" and "c" of paragraph 1, of article 428 of this Code; c) the decision of the High Court in the cases of extradition and transfer of the sentenced persons.
} 
may have been made by other co-defendants, has not filed appeal. While referring to provisions of CPC as a whole, we note that in cases of appeal by co-defendants, when it is not related to personal motives, it has legal effects on other co-defendants ${ }^{1}$.

We note that although not explicitly, legislator has incorporated in, Latin principle "beneficium Cohaesionis", benefit of attachment.

Beneficium cohaesionis- is a Latin principle, which shows that effects of appeal or recourse trial also come for co-defendants, who have not filed the appeal. ${ }^{2}$

What is worth addressing is whether such a principle is applicable or not in case of revision, and dilemmas that arise from the practice how are these resolved.

First, we need to understand what happens in a situation with co-defendants when some of them follow the trials in other instances, while some have not exercised the means of appeal.

If we refer to the legal provision for the final decision, it results that according to article 462/3 cited above the decision becomes final for a co-defendant when the conditions provided as above, are meet ${ }^{3}$.

Following this logic, it turns out that the defendant regardless of the stage of the process for the other co-defendants can use the review as a mean of appeal.

Another case for discussion is the situation of co-defendants where only one of them exercises the review. In this case, which will be the effects of accepting the review for the other codefendants?

In the logical course of applying the principle of beneficum cohesion, legal effects of the decision to admit the request for review for other co-defendants must be applicable. The practice of the High Court has followed the same line after the trial of the case Lika and Laska vs Albania by the ECHR, the High Court accepted their request for review and decided to overturn the previous decisions and return the case to the Shkodra Court of Appeals, to be tried with a another trial panel. In the retrial, before Shkodra Court of Appeals, the co-defendant Behar Lika participated in the retrial together with the two applicants despite the fact he had not claim for revision. ${ }^{4}$

Notwithstanding the above, we are of the opinion that the legal basis, regarding the application of this principle in the cases of the review institute remains deficient. Practice will require further interpretation to clarify what will happen in cases where co-defendants are not interested in being part of a retrial, because it was not convenient, as they may have benefited from amnesty or pardon, regarding to this they may have the will not to be part of the reopening trial.

However, in the basis of addressing all these practices, we are of the opinion that the principle of not aggravating the position of the defendant/ reformation in peius should remain. This

\footnotetext{
${ }^{1}$ Criminal Procedure Code, article 425/1

2http://horizontal-facility-eu.coe.int the legal framework for the re-examination and re-opening of criminal proceedings following the finding of a violation by the European Court of Human Rights: an assessment of the legal framework of Albania.

3 See section 2. Final decision, meaning and cases.

${ }^{4}$ www.gjykataelarte.gov.al Decision no. 74 (00-2012-756), date 07.03.2012
} 
principle should remain at the core of the legal reasoning of the courts, when facing these cases.

\section{Procedural Status of the convicted asking for Reviewing.}

One of the main aspects of reopening a judicial process is the determination of the status of the person, subject to the review institute. The procedural position is of essential importance for the convict undergoing review, therefore the state must provide all means to ensure avoiding the violation of rights guaranteed by the European Convention of Human rights.

The Unifying jurisprudence of $\mathrm{HC}$ stipulates that 1 : "In case when the convict's request is accepted and the Criminal College of the High Court, based on the reviewing jurisdiction it has under Article 453 of the CPC, proceeds with the review process, the defendant will continue to have the procedural status of the convict. Acceptance of the request for re-opening the judicial process does not entail the revocation of the sentence or the release of the convict, but only the re-opening of the trial for clarifying new circumstances, in order the court decision to respond to the truth. This fact will occur only if pursuant to Article 454 of the CPC, the Criminal College of the $\mathrm{HC}$, or the competent court, which will adjudicate the case under review, considers it necessary to suspend the execution of the decision, because execution of the decision during the reopening process would have serious irreparable consequences.

Acceptance of the request for review does not change the procedural position from that of the convict to that of the defendant."

Regarding to the decision we can see that the HC relates the changing of the procedural status only with decision of innocence stated at the end of the re-opening trial. "In case the Criminal College of the HC accept the request for reviewing and in the reopening trial process, at the first instance the convicted is declared innocent, procedural status will change in to the defendant. This situation (the status of the defendant) will continue until the new acquittal given after the review becomes final."

The CPC, in its provisions of Chapter IV, article 449 and following, deals in detail with the review institution. Regarding the procedural position of the convict that is subject to review with the undertaking of the reform is explicitly set out in the code, which is. The CPC stipulates that procedural status of defendant remain same until reviewing court decision is take ${ }^{2}$. According to this sanction, we note that the legislature has not linked the change of procedural position with the type of decision taken by the review court explicitly; however, we can see that a number of changes such as this in question came because of the Unifying Practice of HC. Consequently, we continue to stick to the interpretation of the High Court, which links the change of procedural status with the innocence decision taken in the review process.

The practice of the Committee of Ministers, responsible for monitoring the implementation of ECHR decisions, has paid particular attention to the presumption of innocence in cases of reopening court proceedings. In the case of Sadak, Zana, Dicle and Doğan vs. Turkey through Interim Resolution ResDH (2004) 31,2723, the committee of ministers emphasized the standard and importance of the presumption of innocence. The committee in the interim resolution issued asked the Turkish state to take measures to avoid violating the rights of

\footnotetext{
${ }^{1}$ www.gjykataelarte.gov.al , Unifying Decision no. 3, date 08.07.2013.

2 Criminal Procedure Code, article 453/4.

3 https://rm.coe.int/168059ddae, accessed on 10.07.2020
} 
persons who were already under a retrial process by decision of the ECHR. The latter, after receiving the decision by the ECHR and the commencement of the review process, for a period of 3 years was continue to detain, without giving an objective state justification for denying their request for release ${ }^{1}$.

As stated above, the conduction of litigation in the context of the review needs a special importance in order to avoid violation of the rights of the convicted person. Referring to the practice of the ECHR and the Committee of Ministers in the above-mentioned case, this aspect of the judgment should be looked carefully. The principle of presumption of innocence as provided in Article 6 of the ECHR should be applicable to the retrial, which contradicts the procedural position determined in the unifying practice of the HC. The interpretation and elaboration of the $\mathrm{HC}$ regarding to the case, will be an important point in providing a solution in way to bring the implementation of law in line with the standards of the ECHR.

\section{Revision cases}

The review, as an extraordinary means of appeal, requires the detailed presentation of the application cases, in order to avoid abusive cases and to respect the principle of legal certainty and ne bis in idem.

For this reason in the Albanian legislation are foreseen explicitly, which are the cases of applying this mean of appeal, which have been expanded with the undertaking of justice reform. We briefly present what the cases are, in order to dwell in more detail on the changes brought about by the reform regarding the new cases $^{2}$

\section{a. Consistence of judicial decisions}

In CPC is prescribed that reviewing can be applied in case "if the facts stated in the merits of the decision are not compatible with those of another final judgment" This is put with the intention to avoid mistakes made due to wrong interpretation given to the same facts from different courts. Indeed courts cannot contradict each other, which mean that it is not possible for the same facts interpreted differently by different courts. This would show in a way that one of the courts has not been objective in its decision-making and rightly, within the framework and principle of due process, in terms of adjudication by an impartial court, this case is included in the field of re-opening judicial process.

\section{b. Revocation of a civil or administrative court decision}

The CPC determines in detail what is the importance and value of civil or administrative decisions in criminal proceedings ${ }^{3}$. According to this provision, such decisions determine whether a fact has occurred or not. Now that such decision is revoke, it rightly turns out that this fact did not happen and without the criminal fact, we have no criminal offense. As above, in order to have a fair legal process is need that the judicial process to be re-open.

\footnotetext{
${ }^{1}$ https://rm.coe.int/training-manual-on-the-right-to-fair-trail-and-reopening-of-domesticp/16808b7cab. Accessed on 10.07.2020.

2 Criminal Procedure Code, article 450

${ }^{3} \mathrm{CPC}$ article 71 Consequences of civil and administrative proceedings to the criminal proceedings1. A final civil court decision is mandatory for the court that tries the criminal case only pertaining to the fact whether the offence was committed or not, but not about the guilt of the defendant.
} 


\section{c. Appearing or revelling new evidences that at the time of the trial weren't known}

The court establishes its decision and conviction regarding the guilt or not of the defendant based on the interpretation of the facts and evidence presented by the parties in the proceedings. In case that after the decision made, new evidence appears which could change the course of events as well as the court decision; the revision of criminal proceeding needs to apply. In order for this case to apply, certain conditions must be fill:

- Consider evidence according to the meaning given by the code ${ }^{1}$.

- Parties did not know the evidence at trial time, but it existed ${ }^{2}$.

\section{d. Falsification of trial acts or criminal fact}

Now that through a final decision is found the falsification of the act, which was used by the court in the decision making, then the need arises to review this decision due to a fair trial. Same thing happens when the decision is make based on evidence, which are prove to have been false etc. In all cases, acting differently than expected would violate the principle of regular legal process.

In the following, we are representing the new cases added due to amendment of CPC through reform of justice. These provisions are mainly base on Unifying Practice of the HC over the years. In the other hand, changes came as a need for harmonization of the national law with the international standard, referring in this case to the ECHR jurisprudence (Scozzari and Giunta; Assanidze).; (Öcalan; Krasniki; Gençel) and other recommendations issued by EU institutions . Recommendation (2000)2 etc.

Regarding the amendments brought from justice reform, was note that the three new cases implemented as subject of revision, had in common the fact that the three ones were limited through deadlines. The purpose of such a thing is to avoid in somehow the possible abuse that may happen in practice with these cases and in the other hand to guarantee the principles such as legal certainty and res judicata.

\section{e. European Court Human Rights Decision ${ }^{3}$}

First, we should have clear which is the importance and effects of the ECHR decision for the states that has accept this court jurisdiction. If we see in article 46 of the convention, which foresee that the states ratifying this convention has undertaken the obligation to respect and execute the ECHR decision where they are part ${ }^{4}$. The convention in its entirety results that ECHR decision are not obligatory. Regarding to our national law in the articles of the

\footnotetext{
${ }^{1} \mathrm{CPC}$, article 149 /1 "Shall be considered as evidence the information on the facts and circumstances related to the criminal offence, which are obtained from sources provided for by the criminal procedural law, as well as in compliance with the rules defined by it, and serve to prove whether the criminal offence was committed or not, its ensuing consequences, the guilt or innocence of the defendant the level of his/her accountability.

2 www.gjykataelarte.gov.al, Decision No.06 date 11.10.2002.

3 CPC, article 450/d "if the ground for the revision of the final decision results from a European Court of Human Rights judgment making the re-adjudication of the case indispensable. The request shall be filed within 6 months from the notification of that decision";

${ }^{4}$ European Convention Human Rights, Article 46, Binding force and execution of judgments 1 . The High Contracting Parties undertake to abide by the final judgment of the Court in any case to which they are parties
} 
constitution prissily article 5, 17/2,116,122 prescribes that after ratifying from the state international law is applicable and obligatory. The significance of ECHR decision comes out even from the fact that there is a whole mechanism responsible for monitoring the execution of the decision, Committee of Ministers. Additionally this structure function based on a whole regulation, which regulates the process of monitoring and measures that can be taken in case the execution is not done. ${ }^{1}$ Albania has been subject of ECHR decision in several cases, due to this decision of ECHR stipulating revision process, implemented as one of the reason, for which the convicted could ask to reopen a final decision. As we put out this change came as a result of the jurisprudence of ECHR against Albania. Here we can mention Case Laska and Lika vs Albania"2

"The Court concludes that the proceedings against defendant did not satisfy the requirements of a fair trial. There has accordingly been a violation of Article $6 \S 1$ in the present case. The Court observes that when an applicant has been convicted in breach of his rights as guaranteed by Article 6 of the Convention, he should, as far as possible, be put in the position in which he would have been had the requirements of that provision not been disregarded, and that the most appropriate form of redress would, in principle, be trial de novo or the reopening of the proceedings, if requested"3

In all these cases, the ECHR insists in the application of legal remedies, which would enable the reopening of proceedings against these entities, thus referring to the recommendation of the committee of ministers regarding the achievement of restitution in integrum ${ }^{4}$. This recommendation underscores the fact that states must guarantee effective remedies to achieve restitution in integrum, in order to respect the rights of these categories. Referring to

\footnotetext{
1https://rm.coe.int/16806eebf0 Rules of the Committee of Ministers for the supervision of the execution of judgments and of the terms of friendly settlements rule 11 "Rule 11 - Infringement proceedings 1. When, in accordance with Article 46, paragraph 4, of the Convention, the Committee of Ministers considers that a High Contracting Party refuses to abide by a final judgment in a case to which it is party, it may, after serving formal notice on that Party and by decision adopted by a majority vote of two-thirds of the representatives entitled to sit on the Committee, refer to the Court the question whether that Party has failed to fulfil its obligation. 2. Infringement proceedings should be brought only in exceptional circumstances. They shall not be initiated unless formal notice of the Committee's intention to bring such proceedings has been given to the High Contracting Party concerned. Such formal notice shall be given ultimately six months before the lodging of proceedings, unless the Committee decides otherwise, and shall take the form of an interim resolution. This Resolution shall be adopted by a majority vote of two-thirds of the representatives entitled to sit on the Committee. 3. The referral decision of the matter to the Court shall take the form of an interim resolution. It shall be reasoned and concisely reflect the views of the High Contracting Party concerned. 4. The Committee of Ministers shall be represented before the Court by its Chair unless the Committee decides upon another form of representation. This decision shall be taken by a two-thirds majority of the representatives casting a vote and a majority of the representatives entitled to sit on the Committee ${ }^{2}$ https://hudoc.echr.coe.int/fre\#\{\%22itemid\%22:[\%22001-98349\%22]\}, accessed 13.07.2020 3 See also cases Caka v. Albania, 44023/02,, 8 December 2009;; Xheraj v. Albania, no. 37959/02, § 82, 29 July 2008; Öcalan v. Turkey [GC], no. 46221/99 § 210 in fine, ECHR 2005-IV) Shkalla vs Albania. https://www.legislationline.org/download/id/7430/file/Case_of_Shkalla_v_Albania_2011_en.pdf.acces sed ECHR has argued in the same way, asking the states to guarantee the reopening of cases in such situations.

${ }^{4}$ https://search.coe.int/cm/Pages/result_details.aspx?ObjectID=09000016805e2f06, accessed 13.07.2020
} 
the above and the Albanian state considered necessary to harmonize the legal framework with the international one, in terms of respecting the rights of individuals.

\section{g. Revision, condition for extradition}

In practice, there have been cases when states require appropriate guarantees in order to allow the extradition of persons wanted by justice to be prosecuted or to execute their sentences. One of the most famous cases, who highlighted not only the legal shortcomings but also the diplomatic relations of the Albanian state, was the case of Florian Meçe. The latter was wanted by Albanian state to serve the sentence, which was given in his absence. Following searches, justice authorities were able to identify his location in Spain. Albanian authorities request the extradition of this person from Spain. The extradition made possible by a decision of the Spanish National High Court, after they asked a guarantee for retrial of the subject, due to the issuance of a court decision by the Albanian courts, in his absence. As confirmed by case no. 1549/1 Prot. OF, dated 25.02.2010, by the Albanian state, through the Ministry of Justice, a guarantee was gave for the observance of the right to retrial of the subject, pursuant to the Constitution and articles 147, 148, 449, 450, 453 of the Code of Criminal Procedure ${ }^{1}$. After the extradition due to the legal vacuum, the Albanian state failed to respect the given guarantee, which ECHR expressed too, concluding that we have a violation of Article 6 by the Albanian state. To avoid similar situations it was foreseen in the code as one of the review cases and when required by the states as a guarantee for extradition. ${ }^{2}$

\section{j. Judgment in absentia ${ }^{3}$}

One of the rights that a person enjoys is the right to be present in a trial that takes place against him. Despite this right, legislation in many countries recognizes the trial in the absence of defendants, taking measures to guarantee their rights through a lawyer determined by the court. However, the effectiveness of a defender mainly, practices shows that leaves much to desire. The Albanian legislation provided for the only appeal against the decisions given in the absence of reinstatement in time, which was applicable only if you prove that there was an objective reason, which led to the loss of the time limit for appeal. While as we quoted above did not regulate the situation when the defendant was not at all aware of the criminal proceeding against him. In the framework of the harmonization of the law with international acts, the legislature with right, established trial in absentia, as one of the cases for the reopening of court proceedings 4 . Conducting a trial in such a situation violates due process of law, and one of the rights of the defendant, to be hear and to be present at the trial. Acting contrary to what was said above would lead to violation of Article 6/1 of the KEDNJ. The latter

\footnotetext{
1 www.gjykatakushtetuese.gov.al Constitutional Court decision no. 21, date 29.04.2010.

2 CPC, article $450 / \mathrm{dh}$ "if the extradition of a person tried in absentia is granted on the explicit condition that the case be re-tried. The request for re-trial may be submitted within 30 days from the date of extradition of the person. The request submitted within that time limit may not be refused." ${ }^{3} \mathrm{CPC}$, article 450 /e "if the person is tried in absentia pursuant to article 352 of this Code and requests the case to be re-tried. The request shall be filed within thirty days from the date he is informed. The request submitted within that time limit may not be refused."

${ }^{4}$ https://rm.coe.int/CoERMPublicCommonSearchServices/DisplayDCTMContent?documentId=090000 16804f7581, accessed 13.07.2020 Resolution (75) 11 On The Criteria Governing Proceedings Held In The Absence Of The Accused, see also Recommendation (2000)2
} 
as stated by ECHR in the decision COOLOZA vs. Italy ${ }^{1 " .}$ Although this is not expressly mentioned in paragraph 1 of Article 6 (art. 6-1), the object and purpose of the Article taken as a whole show that a person "charged with a criminal offence" is entitled to take part in the hearing. Moreover, sub-paragraphs (c), (d) and (e) of paragraph 3 (art. 6-3-c, art. 6-3-d, art. 6-3-e) guarantee to "everyone charged with a criminal offence "the right" to defend himself in person "," to examine or have examined witnesses "and" to have the free assistance of an interpreter if he cannot understand or speak the language used in court " and it is difficult to see how he could exercise these rights without being present".

In the same line, the ECHR confirms in the case of Sejdovic vs Italy where it sets out in detail what are the general principles related to the trial in absentia and that this form of trial violates, listing as follows:

Right to take part in the hearing and to obtain a new trial;

Waiver of the right to appear at the trial;

Right of a person charged with a criminal offence to be informed of the accusations against him;

Representation by counsel of defendants tried in absentia; ${ }^{2}$

The Convention, although it does not prohibit adjudication in absentia, leaves it to the discretion of the contracting parties to provide the effective means of achieving the standards sanctioned by the convention for the conduct of a due process of law.

On the other hand, Committee of Ministers in 1975 approved a resolution, in which were foreseen 9 minimal criteria that states should accomplished during administration of the trials in absentia. ${ }^{3}$

\footnotetext{
1https://hudoc.echr.coe.int/eng\#\{\%22itemid\%22:[\%22001-57462\%22]\} (coloza vs Italy), accessed 13.07.2020

2 https://hudoc.echr.coe.int/fre\#\{\%22itemid\%22:[\%22001-72629\%22]\} (Sejdovic vs Italy), accessed 13.07.2020.

${ }^{3}$ Resolution (75) 11 On The Criteria Governing Proceedings Held In The Absence Of The Accused (Adopted By The Committee Of Ministers On 21 May 1975 At The 245th Meeting Of The Ministers' Deputies) 1 . No one may be tried without having first been effectively served with a summons in time to enable him to appear and to prepare his defence, unless it is established that he hasdeliberately sought to evade justice; 2 . The summons must state the consequences of any failure by the accused to appear at the trial; 3 . Where the court finds that an accused person who fails to appear at the trial has been served (atteint) with a summons, it must order an adjournment if it considers personal appearance of the accused to be indispensable or if there is reason to believe that he has been prevented from appearing; 4. The accused must not be tried in his absence, if it is possible and desirable to transfer the proceedings to another state or to apply for extradition; 5. Where the accused is tried in his absence, evidence must be taken in the usual manner and the defence must have the right to intervene; 6 . A judgement passed in the absence of the accused must be notified to him according to the rules governing the service of the summons to appear and the time-limit for lodging an appeal must not begin to run until the convicted person has had effective knowledge of the judgement so notified, unless it is established that he has deliberately sought to evade justice; 7. Any person tried in his absence must be able to appeal against the judgement by whatever means of recourse would have been open to him, had he been present; 8. A person tried in his absence on whom a summons has not been served in due and proper form shall have a remedy enabling him to have the judgement annulled; 9 . A
} 
Our legislation has explicitly defined what trial in absentia mean by placing in a separate provision, the definition of this category and the manner of conducting the process for the latter. ${ }^{1}$

According to this legal provision, in absentia refers only to those persons who have not become aware of the trial conducted and the decision given against them, thus rightly excluding persons who evade justice. After the search according to the legal provisions, the court suspends the trial for a period of 1 year. After a year, if the defendant is not found the trial continues by assigning a defence mainly.

From the analysis of the legal provisions, we can conclude a shortcoming of this trial in relation to the special forms of trial; here, we are referring to the abbreviated trial. According to the provisions governing this trial, it turns out that the defendant can file a request for summary judgment until the preliminary hearing ${ }^{2}$, while if we refer to the review process, it turns out that this stage of the process is exhausted and goes directly to the trial, consequently the defendant loses the right to seek summary judgment.

We are of the opinion that the legislator should make an intervention in the legislation and include the review as one of the cases when the request for summary judgment could be submit during the trial phase on the merits.

\section{Review Procedure and Judicial Practice}

The law defines in details, which are the procedural stages a reviewing request goes through. The legitimate subject (the convicted person or the representative with special authorization

person tried in his absence, but on whom a summons has been properly served is entitled to a retrial, in the ordinary way, if that person can prove that his absence and the fact that he could not inform the judge thereof were due to reasons beyond his control.

${ }^{1} \mathrm{CPC}$, amended; Article 352 Trial in absentia (1. When the defendant in Free State, despite the searches pursuant to articles 140-142 of this Code, fails to appear in the hearing and it turns out that he has not been personally informed of the trial, the court shall decide its suspension and shall order the judicial police to continue the search of the defendant. After one year from the date of suspension of the trial for this reason and, at any time, when there is information on the location of the defendant, the court shall resume the trial, by ordering the repetition of the notification. The court shall declare the absence of the defendant if, even after the newly conducted searches, the defendant is not found. In this event, the trial shall be held in the presence of the defence lawyer." 2 . The court shall declare absence of the defendant, if it is proved that the defendant is escaping from. In this event, trial shall be held in the presence of the defence lawyer. 3. The court shall declare absence even when it is proven that the defendant is abroad and it is impossible to extradite him. 4. The decision declaring absence is invalid when it is proven that such absence it due to his/her the absolute impossibility to appear. 5 . When the defendant appears after the decision declaring his absence has been announced, the court shall revoke it. When the defendant appears after the judicial trial is declared closed, he may ask to be questioned. All actions performed before this moment shall remain valid, but if the defendant requests and the court deems it necessary for the decision to be taken, it may decide the re-opening of the judicial trial and the obtaining of the evidence requested by the defendant or the repetition of procedural actions. 6 . Trial in absentia shall not be held in the case of a minor defendant. In such event, the court, after conducting the searches pursuant to articles 140-142 of this Code, shall decide the suspension of the trial. The rules of paragraph 1 of this article shall apply; to the extent they are compatible.

2 CPC, amended article 403-406 Abbreviated Trial. 
and the legal custody, family members when he / she dies, the prosecutor) ${ }^{1}$ prepares the request, which he / she submits to the court of first instance that have given the decision. Before the changes brought by the reform, the competence to review the revision requests belonged to the High Court. The latter, being a court of law, was necessary to remove the reviewing jurisdiction, which in this case constitutes a trial of fact, a competence, which has passed to the courts of first instance that is a court of fact. The latter examines the request in the deliberation room, without parties' presence and after deciding on its admissibility sends it for retrial to the court of first instance or that of appeal, according to the fact if the challenged decision belongs to first instance or appeal court. ${ }^{2}$

Debate rose among law scholars over the transfer of this competence to the court of first instance. Such a theory is unsupported by scientific reasoning. In our opinion, we do not have any kind of violation in this case; we can even say that in this way the rights of the parties to a criminal process are better guaranteed. We note that the court of first instance does not address the merits of the case; it examines whether or not the request of the subject is based in one of the cases provided by law that legitimizes the review, and whether relevant evidences are presented to prove one of the cases elaborated as above. In this case is not violated principle of degree of judgment, but also the opposite is guaranteed such a principle, thus guaranteeing the right of access of the parties to the legal system. Attached to the request for review the applicant must have evidence justifying the review under the law as well as the appeal against the decision they are challenging.

The request is examined in the deliberation room without the presence of the parties. The question arises; a judge or a judicial body will carry out the review of the request. In our opinion, to give answer to this question we can refer on types of criminal offenses. Jurisdiction in this case should be decided referring to Article 13 of the CPC. ${ }^{3}$

1 CPC amended, article 451 "The following persons may request the revision: a) the convicted person, the defence lawyer specifically authorised by him or his legal guardian, and, if the convicted person has died, his heir or relative; b) the prosecutor attached to the court having issued the decision."

2 CPC amended, article 453/3 "If the request is admitted, the Court decides to send the case to another panel of the same court for re-trial. This decision is not subject to appeal

3 CPC amended "Article 13 Criminal of first instance and their composition (Changed by law no 9911 dated 05.05.2008, article 1) (Amended by Law No. 9911 of 05.05.2008, article 1) (Amended by Law No. $35 / 2017$ of 30.03 .2017 , article 8) 1. Criminal offences shall be adjudicated in the first instance by judicial district courts and by the Anti-Corruption and Organised Crime Court, pursuant to the rules and responsibilities provided for by this Code. 2. The judicial district courts and the Anti-Corruption and Organized Crime Court of first instance rule, by a single judge, on: a) the requests of the parties during the preliminary investigations; b) the appeal against the prosecutor's decision on the noninitiation of the criminal proceeding or on the dismissal of the case, as concerns misdemeanours; c) the request of the prosecutor to dismiss the charge or the case, as concerns crimes; ç) the request of the prosecutor to send the case to trial; d) the request of the prosecutor for the approval of the penal order; $\mathrm{dh}$ ) the requests related to the execution of the criminal decisions; e) the requests on the reinstatement of time limits; ë) the requests related to jurisdictional relations with foreign authorities pursuant to Title X of this Code; f) any other requests provided for by this Code or by special laws. 3. The judicial district courts examine, by a single judge, criminal offences that are sentenced with a fine or with imprisonment for, at maximum, not more than 10 years. The other criminal offences are examined by a panel composed of three judges. 3/1. The Anti-Corruption and Organized Crime Court rules with a judicial panel composed of three judges, unless provided otherwise by this Code. This court examines with a single judge the criminal charges against public officials, pursuant to article 75/a of this Code, 
Regarding to this provision we can notice that if a single judge gives the decision in the first instance, request for review of this decision will be with one judge, while if it is given by a panel of three, the request for revision will be examined by three judges. Furthermore, after assessing whether the conditions for the implementation of the review institute, are met, the court decides on its acceptance or not. The acceptance decision unappealable, in order to avoid delays in the court process. As we can see, the court can only comment on the admissibility criteria of the request and not on the merits of the case, which relates to the evaluation of the evidence and the trial as a whole. Failure to do so would undermine due process and the principle of equality of arms, as the parties are not present. Principle on which the constitutional court has also ruled with a decision stating that: "The Constitutional Court reaffirms its position that the participation of the parties and respect for the principle of equality of arms and the principle of adversarial proceedings are important elements of a due process of law, within the meaning of Article 42 of the Constitution of the Republic of Albania. Regarding to this, the court hearing the case is obliged to take all necessary measures for the participation of the parties or their representatives in the process, which gives them the opportunity to express their views on the factual and legal aspects of the case at trial"

After the acceptance decision, the case will be sent to the competent court for the reopening process. During this stage, the convicted will continue keeping the same status until the trial is over. $^{1}$

As above after acceptance, the case is send to the firs or appeal court for judging. The court must apply the provisions of the first instance trial, within the limits of the grounds presented in the request for review. ${ }^{2}$ The court valuate the new evidences came out in relation with the existed ones in way to conclude with a fair decision.

On the other hand regarding to the effects of the revision over the execution of sentences, we see that accepting the request for reopening a trial does not mean that execution of sentence is suspended. Only through a request to the court, can be suspended. However, states must be careful in such situations to avoid the continued violation of the rights of the individual, following the execution of a decision under review. ${ }^{3}$

During the implementation of the latest changes undertaken from the reform relating to this mean of appeal, there have been raised different issues. For this purpose, we took for study the decision of first Court of Tirana in 2019, whose subject was revision. From the study done results as follows ${ }^{4}$ :

First there is confusion between two extraordinary means of appeal (reviewing and Reinstatement in the time- period) regarding the case in absentia. The convicted instructed not correctly by their defendant, did not use the appropriate legal remedy to challenge the

\footnotetext{
for criminal offences other than corruption and organized crime, punishable by fine or up to 10 years' imprisonment, in the maximum term. 4. Minors and young adults are adjudicated by the relevant court sections, established by law. These sections adjudicate also the adult defendants accused of criminal offences committed against minors. 5. Provisions of paragraph 4, of this article, do not apply in the cases referred to in paragraph 1 , of article 80 , of this Code.

${ }^{1}$ See section 3 "Procedural Status of the convicted asking for Reviewing."

${ }^{2}$ CPC amended article 455/2

3 See as above explained cases Sadak, Zana, Dicle dhe Doğan vsTurkey.

${ }^{4}$ www.gjykataetiranes.gov.al we have analysed the decision of the first instance given for the year 2019.
} 
court decision. This is because they still do not understand what we mean by trial in absentia, where the defendant is neither part of the process nor aware of the trial and what does it mean when the defendant is aware of the process that takes place against him but for objective reasons finds it impossible to be present. Out of 33 decisions that had as object of review, in 21 cases the convicted claimed that he was tried in absentia, in these 21 cases only in 8 of the cases the court accepted the claim together with the request for suspension of the execution of the sentence in question. Meanwhile, in one of the cases the court stated that the execution of the decision would continue because before the sentence the person had been under the measure "Precautionary detention in prison", justifying in this case the continuation of the execution with the associated danger posed by the subject based also in the criminal offence committed and convicted about. In other cases, court refused the claim for revision because the complainer did not fulfil the legal conditions foreseen in the code for revision, as:

Not submitting the claim within the deadline foreseen in the code with the last approved changes;

Not submitting the evidences legitimating the request;

Decision were not res judicata, which means the ordinary mean of appeal were still in force and could be used by the convicted, so with other words it was not a final decision.

Only in 10 cases, court argued non - acceptance decision with the justification that the decision asked for revision was not a trial in absentia.

As above, results that the court are really carefully and give a special attention to the reviewing institution, by analysing in details each component of this institution. On the other hand, we cannot say the same thing for the defendants, which need further training and elaboration in the new provisions implemented and especially about the trial in absentia.

\section{Conclusions and Recommendations}

Review is an important procedural institute, which is implemented in the framework of respecting the rights of individual's due process of law, avoiding the limitations and barriers created by legal proceedings after the decision becomes final.

At the core of this institute is the administration of justice regardless of the fact when it is ascertained. This mean of appeal has evolved through years by improving, with the purpose to guarantee the rights of parties in the process due to a fair trial. These changes came out as need to harmonize the national law with the international one, and in the other hand an important source for these changes was the unifying practice of the HC. Regarding to the above-mentioned sources justice reform undertook new provisions relating to the revision, as a mean of appeal and cases when this procedure may be applicable. Despite those changes, there are also situations that need intervention through legal changes or interpretation from the High Court.

First putting preliminary hearing as an intermediate phase on the process by not analysing in appropriate way its application, has violate some rights of the offender who has been judged in absentia. During the reopening process, we can see that the reviewing refers only for the phase of trial on the merits, so that phase of preliminary hearing is considered done and so is no need to repeat during the revision process. This provision does not allow to the convicted to submit the request for Abbreviated Trial, as far as this request can be submitted only in the preliminary hearing phase. Our recommendation is that article 403 to be changed, and right 
for abbreviated trial to be submitted also after the preliminary phase is done or the suspension of the process during trial in absentia to be done as it is in Italian system, since in the preliminary hearing phase.

Additionally regarding trial, in absentia court must ensure as possible a complete restitution in integrum as long as the offender has not been part of the process and there was no knowledge related to the process against him.

In the first point of view, it seems that the regulation of trial in absentia has found an establishment in accordance with EU standards. Further must be wait to see the implementation through practice of courts.

Secondly, an important issue is the legal effects that have a decision for the co-defendants when for one the decision is res judicata and for the others they are still in the process in the other instances. In our opinion, in cases where the reason for the review of the decision is related to the merits of the case, the circumstances of the criminal fact and its authorship must certainly be taken into account and for the other co-defendants; in the context of judicial consistency, courts cannot be to be contradictory to each other in decision-making.

Even though this provision must be taken in consideration and to be pay a special attention cases when the co- defendants doesn't want to be part of the reviewing process regarding to the principle of beneficium cohesion.

Thirdly, regarding the suspension of sentences execution it is let in discretion of the court, after the convicted claims, to decide whether it must be suspended or not, in our opinion there the law must put some criteria's that, conditions based on which the court should refuse or not the request for suspension of execution. In this way, we avoid decision, which violates the rights of the accused in an unjustified way.

Fourthly, regarding the reopening process, the legal provisions seem to comply with the EU standards by giving the opportunity to the accused challenge the evidences against him, respecting his right to be heard in a trial. Further, implementation in practice of these legal provisions will be see.

Another problem are the transitory provisions, the lawmaker dint foreseen what happens with the cases that were in the HC before changes were implement. The practice will be confused relating to these cases; anyway, the courts must be carefully to avoid the violations of accused rights.

Finally, sanctioning of this extraordinary mean of appeal by the legislator is in line with the rights to conduct a due process of law, respect for the rights of the defendant and what is most important serves the purpose of the law, the administration of justice and the discovery of the truth.

\section{References}

[1] Constitute of Republic of Albania;

[2] European Convention Human Rights

[3] Protocol no. 7 of the European Convention on Human Rights;

[4] Explanatory Report to the Protocol 
[5] Resolution (75) 11 On The Criteria Governing Proceedings Held In The Absence Of The Accused,

[6] Rules of the Committee of Ministers for the supervision of the execution of judgments and of the terms of friendly settlements rule

[7] Recommendation (2000)2 Recommendation No. R (2000) 2 of the Committee of Ministers to member states on the re-examination or reopening of certain cases at domestic level following judgments of the European Court of Human Rights

[8] Directorate-General for Human Rights Council of Europe F-67075, Strasbourg Cedex "The right to a fair trial", p. 65;

[9] Law No.7905, date 21.3.1995 Criminal Procedure Code of the Republic of Albania, amended ;

[10] www.gjykatakushtetuese.gov.al

[11] www.gjykataelarte.gov.al;

[12] www.gjykataetiranes.gov.al

[13] http://www.gjykataelarte.gov.al/web/Vendime_Unifikuese_39_1.php;

[14] https://hudoc.echr.coe.int/eng\#\{\%22itemid\%22:[\%22001-58337\%22]\};

[15] http://horizontal-facility-eu.coe.int

[16] https://rm.coe.int/168059ddae;

[17] https://rm.coe.int/training-manual-on-the-right-to-fair-trail-and-reopening-ofdomestic-p/16808b7cab

[18] https://rm.coe.int/16806eebf0;

[19] https://hudoc.echr.coe.int/fre\#\{\%22itemid\%22:[\%22001-98349\%22]\};

[20] https://www.legislationline.org/download/id/7430/file/Case_of_Shkalla_v_Albania _2011_en.pdf;

[21] https://search.coe.int/cm/Pages/result_details.aspx?ObjectID=09000016805e2f06;

[22] https://rm.coe.int/CoERMPublicCommonSearchServices/DisplayDCTMContent?doc umentId=09000016804f7581;

[23] https://hudoc.echr.coe.int/eng\#\{\%22itemid\%22:[\%22001-57462\%22]\};

[24] https://hudoc.echr.coe.int/fre\#\{\%22itemid\%22:[\%22001-72629\%22]\};

[25] http://horizontal-facility-eu.coe.int 